Bouckaert, G. \&Van de Walle, S. (2003). Comparing measures of citizen trust and user satisfaction as indicators of 'good governance': Difficulties in linking trust and satisfaction indicators. International Review of Administrative Sciences, vol. 69, nr. 3: 329-344

\title{
Comparing measures of citizen trust and user satisfaction as indicators of 'good governance': Difficulties in linking trust and satisfaction indicators ${ }^{1}$
}

\author{
Geert Bouckaert ${ }^{2} \&$ Steven Van de Walle ${ }^{3}$
}

\section{Introduction}

Until recently, public administration mainly used so-called 'hard indicators' (like e.g. resources and output) to monitor performance. Increased attention for accountability and the problems that have emerged in relating input, activities and output with effects have stimulated the introduction of 'soft' indicators (e.g. satisfaction targets in the budget, Government of Western Australia, 2000). Information on the functioning of separate agencies and programmes is no longer satisfying citizens, politicians, and, indeed, researchers. Instead, there is a demand for information on 'governance' as a whole. The recent attention for 'quality of life' indicators indicates this (Bennett, Lenihan, Williams, and Young, 2001). The turn to so-called 'soft' indicators is a sign of the emancipation of public management and public administration studies from economics, business and management faculties.

The World Bank defines governance as "the manner in which power is exercised in the management of a country's economic and social resources for development" (World Bank, 1992). Governance refers to steering and has to do with the ability of human institutions to control their societies (Peters, 1995). In its more practical use however, good governance often turns out to be a very broad and value-laden concept (Kofele-Kale, 1999). It is used in the public arena to discourage certain government actions and to promote others, even though the governance definitions themselves do not frequently contain such ethical/moral arguments.

\footnotetext{
${ }^{1}$ The authors want to thank Elke Löffler, Tony Bovaird, Jarl Kampen and two anonymous reviewers for their helpful comments.

${ }^{2}$ Director, Public Management Institute, Katholieke Universiteit Leuven, Belgium

${ }^{3}$ Researcher, Public Management Institute, Katholieke Universiteit Leuven, Belgium
} 
Politicians, journalists and citizens increasingly express their worries about a decreasing trust in government and the detrimental effects this has on government and on the cohesion of society (Bok, 2001). The underlying hypothesis of these politicians, public administrators and journalists, but also of most researchers is that more trust and more satisfaction equal better governance. Increasing the quality of governance will thus also lead to citizens who are satisfied and more trusting. When trust and satisfaction are used in the general discourse, they are supposed to measure citizens' evaluation of the quality of the steering of society and of the direction in which society is steered.

This discourse contains a very mechanistic reasoning: increasing the quality of governance will increase satisfaction and trust, and therefore trust and satisfaction indicators can be used as proxies for good governance. This article wants to show that current attempts to measure trust and satisfaction in government are misleading if they claim to be measuring good governance, and this for two reasons.

- Satisfaction has shown itself to be elusive to measure, and very service-specific making it a rather less meaningful indicator when aggregated. It can only be interpreted in relation to the significance of a given service and responses are easily swayed by the broader public mood.

- Trust in government is perhaps easier to measure but its linkages with good governance are far from clear. Even though it is trust in government that is measured, it is not at all clear whether the level of trust is actually influenced by governmentrelated factors.

A careful research design may help to deal with these problems, but even then, a number of problems remain:

- in using satisfaction as an indicator

- in using trust as an indicator

- in relating satisfaction with the functioning of public services, trust in government and 'good governance'

The following paragraphs will deal with each of these three issues.

\section{Satisfaction}

The attention given to satisfaction indicators, and indeed subjective indicators in general, is not new. The end of the 1970s and beginning of the 1980s showed an increase in surveying and satisfaction surveying more specifically, especially with regard to local services (Stipak, 
1979). Since the beginning of the 1990s, developments in the measurement instruments and research at economic and marketing departments, and the increased attention for assessing customer orientation in the public sector, stimulated attention for satisfaction surveying. The data generated by these surveys are often used to create benchmarks, to compare services, to evaluate the management or to reconsider funding.

The renewed attention in the 1990s to customer satisfaction started in Northern America, with the development of Servqual, an instrument for measuring customer satisfaction in service industries, as an important landmark (Zeithaml, Parasuraman, and Berry, 1990). In the context of government, we should mention the American Customer Satisfaction Index, the Canadian Common Measurements Tool (Schmidt and Strickland, 1998), and many local initiatives. These initiatives have been followed swiftly in Europe, as is shown by a broad range of applications in the UK (Moore, Clarke, Johnson, Seargeant, and Steele, 1998), the Swedish Customer Satisfaction Index, and by an increased attention in Central Europe (SIGMA, 1998). In the Netherlands, the Court of Audit did a meta-analysis of client surveying actions (Algemene Rekenkamer, 1997), a fiscal monitor was developed (van Kruchten and Peereboom, 1997), and instruments have been developed to guide local authorities' initiatives (Programmabureau Overheidsloket , 2000). In Belgium, the use of a standardised instrument at the federal level, the Quality Barometer, has somewhat slowed down, but at the same time, a steering committee was started within the ministry of the Flemish Community to coordinate all initiatives within the ministry (Bouckaert, Kampen, Maddens, and Van de Walle, 2001).

Variations in the measurement instruments however mean that an aggregated use of satisfaction data remains difficult. Even more important is to know what these data mean and how to interpret them. The most important question is one about construct validity; what does 'satisfaction' in fact measure?

\section{What does satisfaction mean?}

In satisfaction surveys, a direct causal relation is presupposed between the quality of a certain service delivery and user satisfaction. If service quality increases, satisfaction increases as well. In reality however, this is not always the case because of (Bouckaert, 1995):

- differences in producer and consumer views on quality

- changes in quality and perceptions of it, but also of expectations

- $\quad$ service characteristics 
All these factors thus have to be taken into account. A single satisfaction indicator does not tell us enough about the reasons for a certain level of satisfaction.

In methodologically sound satisfaction surveys (which are still the exception rather than the rule), clients are not only asked about their satisfaction with a certain aspect (e.g. friendliness speed...), but also about the importance of these aspects. A 99\% satisfaction with fire fighters' friendliness will probably not contribute to overall satisfaction if the speed of intervention is extremely low. These questions on importance allow us to discover whether most respondents base their responses on the same aspects of service performance, something little is known about (Stipak, 1979).

More quality does not necessarily lead to better evaluations because citizens' expectations change as well. Some even suggest that it are expectations and not different service performance that determines satisfaction (Conroy, 1998). If the emergence of expectations would be influenced by individual characteristics, the use of satisfaction indicators would not be problematic, since expectations would then only depend on experiences and knowledge. Expectations however, and indeed perceptions of how a certain service functions, do not only originate from individual-level citizen-service interaction. Social interaction also influences what citizens will expect from services, and even the way how they perceive the functioning of these services (Van de Walle, forthcoming).

A meta-analysis of satisfaction surveys in the US by Miller and Miller found that fire departments usually receive higher ratings than for instance road-repair services (Miller and Miller, 1991). This seems to depend on certain service characteristics. Both Das et. al. and Roth et. al. have shown that the evaluation of services depends on service characteristics (Das, Das, and Mckenzie, 1995; Roth, Bozinoff, and MacIntosh, 1990). Frequency of use, homo- or heterogeneity of the service and directness of contact with the service all have an influence on customer satisfaction, independent from service quality (Dinsdale and Marson, 1999). Most customer satisfaction surveys focus on how something is done and not on what is done. Satisfaction depends on whether one has sympathy for what the agency does (mission), and whether one thinks what the agency is doing is good for society. Research by the Pew Research Center found a relation between satisfaction and whether one could identify oneself with the mission of the agencies concerned (Princeton Survey Research Associates and Pew Charitable Trust, 2000).

\section{How to interpret the results?}

Customer satisfaction surveys and the public discourse surrounding a certain agency are often disconnected. People generally complain about public services and civil servants, while this is not often reflected in satisfaction surveys or in the number of complaints. Private sector is 
generally said to function better than public sector, but then the actual situation as measured in satisfaction surveys does not match this public discourse (Poister and Henry, 1994). Other numbers confirm this: The 2002 American Customer Satisfaction Index results indicate that satisfaction with federal government services is very similar to satisfaction with private sector companies. US Government even prides itself of having overtaken private sector slightly (Peckenpaugh, 2001). Even though the results should be interpreted with care, since government agencies participate in the ACSI surveys on a voluntary basis while private companies do not, we can at least observe the absence of major differences between private and public service satisfaction. We observe a similar tendency in the results of the Kundenmonitor in Germany (Servicebarometer AG, 2001). Katz et. al. did research on the differences in public and private sector appraisal, and found that respondents can choose for a pragmatic (genuine evaluation of the quality) or an ideological (i.e. public sector is worse than private sector) answer in surveys, and that this choice can be influenced by how the questionnaire is constructed (Katz, Gutek, Kahn, and Barton, 1977).

Goodsell noticed that citizen's opinions towards public services become more positive when the questions asked become more concrete (Goodsell, 1994) and Rouban found that ratings of specific services are positive and do as such contradict the negative public opinion on government in general (Rouban, 1995). Satisfaction surveys only reveal part of the picture, and should therefore be approached with care. Levels of satisfaction may just as well reflect a certain mood as they reflect an evaluation of service quality, and when and how this will happen depends on the survey context

\section{Trust}

Trust in government, parliament or the civil service has received increased attention in recent years (Panel on civic trust and citizen responsibility, 1999; Sims, 2001). Trust is more general than satisfaction, and serves as a very handy and easily accessible indicator. Most of the comments referred to in the satisfaction paragraph apply to trust as well. In this paragraph, we will only add a number of specific comments which will show that high or low levels of trust cannot only be attributed to the good or bad functioning of institutions (Van de Walle and Bouckaert, 2003). Levels of trust in government may even be entirely unrelated with what government is or does.

A general comparison of levels of trust in government in different countries does not take into account philosophical discussions on the necessity and desirability of trust in government (Parry, 1976). Most research focusing on Western Europe regards trust in government as indispensable for government to function. In Anglo-Saxon research on the other hand low 
trust is an expression of a healthy democratic attitude, since high levels of trust facilitate repressive government. This means there is always a certain cultural-political bias in trust attitudes. A high level of trust and satisfaction does not always reflect that what is commonly called "good governance". Authoritarian rulers often enjoy a high level of demonstrated public trust, and clientelistic relations often lead to a high level of satisfaction. Trust and satisfaction indicators thus always have to be interpreted within their specific context.

The level of trust thus seems to be, at least partly, culturally determined (Hofstede, 1980). This does not mean trust is a constant. Instead, the nature of trust in government is changing. The meaning and content of the term has changed, because points of reference have changed. Where trust in government used to refer to belief that government will not become autocratic or arrest people indifferently, it now refers to more down to earth matters such as reliability of service delivery or the expectation that policy will correspond to one's wishes.

The factors determining trust in government are not necessarily the same for every country or political culture, and may differ over time. In political systems where public services are functioning in an impeccable way, evaluations of the public services will probably not be used to determine one's level of trust in government. Even more important is the impact of events: how can the impact of a certain event be filtered from the trust score? It is known that events have an -often temporary- impact on the level of trust in government, as was for instance shown by the upsurge of trust in the US just after the $11^{\text {th }}$ of September (Light and Labiner, 2001), or by the changes of trust in the police/juridical system and the press just after (respectively very low and high) and one year after (resp. again rising and a dramatic downturn) a paedophilia-affair in Belgium.

If it is even not clear what influences trust in government, and whether it actually has to do with government, it is difficult to research the relation between good governance and the level of trust. It thus seems that the question "what influence does A (here: good governance) have on trust?" can only be answered by answering the question "apart from A, what else has an influence on trust?", and "is the influence of A a constant in time and space?". 


\section{Can trust and satisfaction be used as indicators for 'good governance’?}

The topic of this article is how trust and satisfaction can be used as good governance indicators. The rationale is that high levels of trust and satisfaction are indicators of good governance. As the previous paragraphs have tried to show, there is not even a bit of clarity on the real origins of trust and distrust in government.

\begin{tabular}{|c|c|c|c|}
\hline 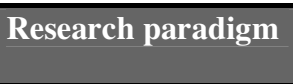 & $\begin{array}{l}\text { Diagnosis: reasons for } \\
\text { low trust in government }\end{array}$ & Citizens' reaction & $\begin{array}{l}\text { Restoring trust: } \\
\text { remedy }\end{array}$ \\
\hline Management & Failing performance & Exit/voice/loyalty & Quality services \\
\hline $\begin{array}{l}\text { Public } \\
\text { administration }\end{array}$ & $\begin{array}{l}\text { Failing performance } \\
\text { because of government } \\
\text { overload }\end{array}$ & Exit/voice/loyalty & $\begin{array}{l}\text { Expectation } \\
\text { management }\end{array}$ \\
\hline Sociology & $\begin{array}{l}\text { Distrust \& societal } \\
\text { discomfort }\end{array}$ & $\begin{array}{l}\text { Exit/voice/loyalty, } \\
\text { Anomy... }\end{array}$ & $\begin{array}{l}\text { Social Capital, } \\
\text { Norms, Identity }\end{array}$ \\
\hline Economy & Principal-Agent & $\begin{array}{l}\text { Co-operation, } \\
\text { polarisation }\end{array}$ & Participation \\
\hline
\end{tabular}

Table 1: theoretical frameworks for trust

Trust in government has never really disappeared from the research agenda, but still we observe an increased attention for the topic in recent years. Different research paradigms offer different diagnoses and remedies. Some of these approaches relate trust in government to factors that are external to government. The differences in the approach of the main research traditions do not only offer different remedies for restoring trust in government, their diagnoses of the reasons for distrust are different as well.

Management theories explain the absence of trust in government by referring to the bad performance of systems, i.c. government, and trust can be restored by improving service quality. Failing government performance stimulates citizens to make an increased use of their possibilities for exit (using other services if possible, not paying taxes) or voice (voting for other party, complain). Whether and to what extent these two options will be used depends on the degree of loyalty towards government (Hirschman, 1970). Public administration approaches also relate performance and trust. The difference is that (bad) performance is caused by government overload: government is not (no longer) able to meet rising demands, or citizens' demands are just contradictory. The proposed remedy is accordingly expectation management: government can stimulate citizens to attenuate demands or point to the conflicting nature of certain demands. Sociological theories see distrust as a broader societal phenomenon, leading to a number of reactions, among which exit/voice/loyalty and anomy. 
This broad approach also suggest there is not one single remedy to restore trust, and that it is not sufficient to change government to restore trust in government. Economists approach the problem of trust from a principal-agent framework. Depending on the presence or absence of trust there will be co-operation or polarisation, and participation can create trust, because it identifies and eventually harmonises interests and makes actions predictable

These different research approaches touch upon elements that we also find in the discussion on good governance (participation, quality services, ...). Using these similarities to suggest that trust and good governance would be the same or similar concepts however is a bridge too far. Some of the factors that are often used to explain trust in government and satisfaction clearly fall out of the scope of what is commonly understood under governance. Trust and satisfaction are influenced by a score of societal and psychological factors. Other evidence deals with differences in the conception and nature of trust and good governance indicators. In what follows, we show why using trust as an indicator for good governance is a risky undertaking.

In fact we have to answer three different questions: 1) are trust and good governance similar or comparable concepts 2) does good governance lead to trust in government and 3) is trust a necessary precondition for good governance.

\section{Are trust and good governance similar or comparable concepts?}

Trust in government indicates congruence between citizens' preferences and the perceived actual functioning of government. When there is trust, this does not necessarily mean that government is functioning in a way that would -normatively- be described as good governance, instead trust means that government is functioning in the way that is preferred by citizens (or better: is perceived to function -or not to function- like that). In practice however, good governance and the preferred way of the functioning of government will often coincide.

The relation between trust and satisfaction and good governance is ambiguous because of the two possible conceptions of good governance: good governance as a value, with a number of pre-established, universal values (no corruption, equal treatment of all...) and good governance as an expression of the acceptance of the process and system of governing by the citizens and stakeholders. The latter conception is then similar to trust, but it is the first conception that is commonly understood as good governance.

Good governance rests on an objectivated evaluation of a system's functioning. This evaluation rests on a number of criteria (e.g. no corruption, no government favouritism, participation...), which all are (unavoidably) normative. These criteria are considered 
universal because they are humanistic acquis based on democratic constitutions and general declarations on human rights (Universal Declaration of Human Rights, The French and US constitutions, ...) and they are operationalised by experts, though they in most cases also rest on popular convictions. The evaluation of the system can be made both by insiders (those inside the system), as by outsiders (pressure groups, academics...). A change in any of the criteria leads to a change in the extent of 'good governance'. The traditional conception of good governance could thus be interpreted as a monistic and even manicheistic approach to how society should be organised. It is not our task here to question its assumptions, but only to indicate why there is no direct relation between trust in government and good governance.

Trust in government on the other hand is a subjective phenomenon, almost an emotion, and as such, trust in government is always an evaluation by those inside the system. The subjectivity of the phenomenon makes it very difficult to determine which evaluation criteria are actually used. Trust in government can be a factor of how well government functions, of the level of general optimism in society (Uslaner, 2002), of how strong the leader is perceived to be etc.

Citizens use different criteria to evaluate government and consequently to determine their level of trust in government. The formation of a (dis)trusting attitude cannot just be reduced to one single criterion. Citizens use a multitude of criteria, though a certain criterion may weigh stronger on the general evaluation of government in a specific context. Not all citizens do necessarily use the same criteria. For some, the functioning of public services will be an important criterion, while for others this factor is negligible as compared to the honesty of politicians.

Criteria change. What is an important consideration for one person is not considered as important by others. While an efficiently functioning public service is now clearly an important factor in the formulation of one's general opinion toward government, this factor was less important in the past. Different political cultures may use different criteria. While clientelistic relations between citizens and politicians are now generally considered as being old-fashioned and as leading to favouritism, there is a growing recognition of the benefits such a relation may bring. Whether clientelistic relations will promote or destroy trust in government is therefore not that easy to determine.

Evaluation criteria change, but evaluation criteria can also be changed. Information on the negative/positive effects of favouritism may stimulate citizens to include favouritism into their catalogue of evaluation criteria. Similarly, when governments try to present public services as the core of government, the functioning of these services will acquire a larger role in the determination of levels of trust in government, while earlier, this role was taken up by e.g. the functioning of parliament or politicians. 
Changes in evaluation criteria mean that even when the functioning of the public services would improve, this does not necessarily mean that satisfaction with these services and trust will go up, because the functioning of public services is not an important criterion for some, and because the observation of a well-functioning public service may incline citizens to start attributing a higher importance to other criteria. Our overview of research approaches to trust in government also showed that reasons for distrust do not necessarily have to be looked for within government.

Trust and good governance are thus not the same thing. Nevertheless, in most cases criteria used for good governance (e.g. absence of corruption) will also be used as criteria for trust. Similarly, criteria to determine whether there is good governance or not, are based on popular conceptions of what is supposed to lead to trust. This means that both trust and good governance indicators will generate comparable results, but due to the different types of criteria, focus and features of both concepts, this should not be the case. Table 2 provides a summary.

\begin{tabular}{||l|l|l||}
\hline \hline & \multicolumn{1}{|c|}{ TRUST IN GOVERNMENT } & \multicolumn{1}{|c|}{ GOOD GOVERNANCE } \\
\hline $\begin{array}{l}\text { Type of } \\
\text { criteria }\end{array}$ & $\begin{array}{l}\text { Subjective criteria. Concept of trust is } \\
\text { changing. Criteria determining trust are } \\
\text { only stable up to a certain extent. }\end{array}$ & $\begin{array}{l}\text { Objectivated criteria, more or less stable } \\
\text { concept and criteria to determine level of } \\
\text { good governance }\end{array}$ \\
\hline Focus & $\begin{array}{l}\text { Internally defined (only those inside the } \\
\text { system can express trust) }\end{array}$ & $\begin{array}{l}\text { Externally defined (assessments of the } \\
\text { goodness of governance can also be done } \\
\text { by actors outside the system. Criteria are } \\
\text { then as such applicable to all systems) }\end{array}$ \\
\hline Features & $\begin{array}{l}\text { Congruence between actual situation and } \\
\text { criteria for trust is determined } \\
\text { individually, or rather intersubjectively. } \\
\text { Criteria used for trust depend on an } \\
\text { intersubjective process and both choice of } \\
\text { criteria and assessment of the congruence } \\
\text { are socially influenced (i.e. no } \\
\text { objectivated choice of criteria nor } \\
\text { objective evaluation of the actual } \\
\text { situation) }\end{array}$ & $\begin{array}{l}\text { Experts determine criteria for good } \\
\text { governance. Choice of criteria is partly } \\
\text { intersubjective relying on 'what ought to } \\
\text { be' and not so much on perception of } \\
\text { 'what is' }\end{array}$ \\
\hline \hline
\end{tabular}

Table 2: Trust and good governance indicators: types, focus and features

Trust indicators are a result of citizens' perceptions, while good governance indicators are based on measurement that is more objective. The following table tries to give some concrete differences between the indicators and concepts for both trust and good governance. It is purely illustrative, and does not rest on empirical proof. The column on the left gives concepts that may be used to measure trust, while the column on the right shows how these issues are 
(partially) translated into concepts of good governance. The good governance column shows additional concepts that are not based on trust concepts ${ }^{4}$.

\begin{tabular}{|c|c|}
\hline TRUST CONCEPTS & GOOD GOVERNANCE CONCEPTS \\
\hline $\begin{array}{ll}\text { - } & \text { Impartiality \& absence of risk } \\
\text { - } & \text { Certainty } \\
\text { - } & \text { Transparency } \\
\text { - } & \text { Satisfaction with service delivery } \\
\text { - } & \\
\text { - } & \text { Political efficacy and participation } \\
\text { - } & \text { Trustworthy politicians } \\
\end{array}$ & $\begin{array}{ll}\text { - } & \text { Rule of law } \\
\text { - } & \text { Information, Communication } \\
\text { - } & \text { Access to public information } \\
\text { - } & \text { Complaint-handling procedures and quality } \\
& \text { systems } \\
\text { - } & \text { Free and fair elections } \\
\text { - } & \text { Level of corruption } \\
\text { - } & \ldots\end{array}$ \\
\hline & $\begin{array}{ll}\text { - } & \text { independence of civil service } \\
\text { - } & \text { property rights } \\
\text { - } & \text { decentralisation } \\
\text { - } & \text { absence of poverty } \\
\text { - } & \ldots\end{array}$ \\
\hline
\end{tabular}

Table 3: operationalisation of trust and good governance indicators

Creating high levels of trust is sometimes just impossible for government. Distrust in government is not only emanating from government or citizen-government interaction, but it is just as well a social factor (e.g. a general negative attitude toward government that is selfsustaining, a tradition to be very critical towards government...). Easton claimed that specific support can be generated by government (by supplying certain outputs), while diffuse trust can be generated by government and by the population (Easton, 1965). Trust results from congruence between one's wishes/expectations and government policy or the way government functions. Whereas good governance deals with ways of functioning of the state that are supposed to be universally applicable and generally accepted, trust in government can also be present in systems which are not universally applicable or accepted. This means that citizens and the state, and indeed good governance researchers, may have different opinions on what is supposed to be, on how a state is supposed to function. Examples are the different approaches to the role of politics in the state: participatory politics vs. politics as something that is done by an elite (Parry, 1976). Creating congruence between the actual system of governing and citizens' wishes is difficult because the underlying wishes and expectations are not homogeneous. We doubt whether this absence of homogeneous expectations is due to the

${ }^{4}$ For a good overview of good governance concepts, have a look at the World Bank Governance and Public Sector Reform site, where a number of concepts and indicators of governance and institutional quality are listed:

(www1.worldbank.org/publicsector/indicators.htm) 
lack of political sophistication. Instead, we agree with the fact that political systems are always based on a number of (constantly changing) choices between social and political dilemmas. This means that perfect congruence between wishes and the actual situation is difficult to reach.

\section{Does good governance lead to trust in government?}

Good governance is supposed to be reflected in satisfied and trusting citizens. We have mentioned that trust and satisfaction ratings are influenced by other factors as well. It is not clear how the relation between trust and good governance has to be understood: does good governance lead to citizens who trust government, or is it the a-priori attitude towards government (distrust) that leads citizens to evaluate government and governance in a negative way (Van de Walle and Bouckaert, 2003)? Perceptions of governance, even when people have access to objective measures, are not necessarily reflecting the real situation. People with low trust will simply not be able to perceive a large number of positive acts of government, because perception is to a large extent idea-driven (e.g. 'government never does anything good') instead of data-driven (governance indicators show an increase) (Augoustinos and Walker, 1996). A permanent negation of the held stereotypes, this means continued efforts for good governance, may eventually lead to increased trust.

\section{Is trust a necessary precondition for good governance?}

Is then trust necessary to come to good governance? We will deal with two -related- aspects:

- Absence of trust decreases the governance capacity of government

- Absence of trust makes a network organisation of society impossible.

Trust enables governments to act without having to resort to coercion or the use of force for every single decision (Gamson, 1968). Absence of trust in government results in citizens who do not want to pay taxes, who do not obey the law etc, and makes an increase in the number of monitoring systems necessary (Tyler, 1990). It is not known how much trust government needs to function, nor do we claim that good governance is impossible without trust in government. Nevertheless, the policy implication of this observation is that trust-building measures may contribute to good governance. Such trust-building measures never work in a mechanical way, and efforts on only one domain are not sufficient. They include the presence of credible commitments, fair procedures, and reciprocity (Levi, 1996). 
This immediately brings us to the second point. Absence of trust makes a strong government necessary (even though this in turn is a cause for distrust in government). Governance refers to the mode of organisation of society, and can be based on a market, a hierarchy or network type of organisation. Each of these three types requires a guiding principle: in the case of networks this is cooperation and trust (Bouckaert, 1998). Definitions of good governance often emphasize the importance of networks and civil society, and according to these definitions, trust is thus necessary. 'Good governance' seems to take it for granted that policy and services delivered by a network structure result in better outcomes. If good governance is defined as the process of decision-making, reflected in a strong involvement of civil society and based on networks, then the answer on the question whether trust is necessary to come to good governance seems to be corroborated. If however good governance is defined as the outcome (micro and macro) of the governance process, then the need for a-priori trust is less outspoken, since markets and hierarchies may also result in comparable outcomes. In this case, however, trust may still serve as a means to diminish transaction costs.

\section{Final remarks and future research}

Traditional approaches to trust and good governance, both in their diagnoses, reactions and remedies are too simple to explain the relation between trust ( $T$ ) and good governance (GG). The concepts of trust and good governance have a different nature and are therefore not necessarily comparable. We have described the two processes invoked when relating trust and good governance: Trust is necessary for good governance (1), or good governance leads to trust (2)

$$
\begin{aligned}
& \mathrm{T} \rightarrow \mathrm{GG} \\
& \urcorner \mathrm{T} \rightarrow{ }^{\urcorner} \mathrm{GG}
\end{aligned}
$$

$$
\begin{aligned}
& \mathrm{GG} \rightarrow \mathrm{T} \\
& \urcorner_{\mathrm{GG}} \rightarrow{ }^{\urcorner} \mathrm{T}
\end{aligned}
$$

Trust however is not sufficient, as we have suggested by referring to the interference of a large number of other factors, some even not related to the government-citizen interaction. The classic dichotomy between trust and governance cannot be maintained either, since trust 
is both cause and effect. What we have tried to show in this article is a more complex relationship of trust and good governance. As a hypothesis, trust could be Insufficient but Necessarily part of a set of indicators which are Unnecessary but Sufficient for good governance. These are the so-called INUS-conditions (Mackie, 1965). A better operationalisation of the relation between trust and good governance would thus be:

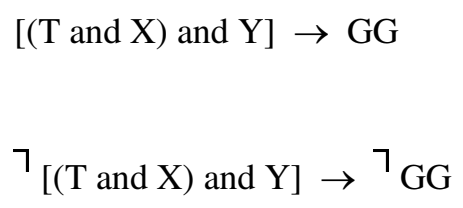

Where X: good functioning of hierarchies, networks and markets

Y: external factors (economic, political, cultural, international,...)

Trust only leads to good governance if $\mathrm{X}$ and $\mathrm{Y}$ are also present. Absence of $\mathrm{T}, \mathrm{X}$ and $\mathrm{Y}$ results in the absence of good governance. To conclude, we could say that in most situations, trust is an indicator for good governance, but it is contingent upon $\mathrm{X}$ and $\mathrm{Y}$. The precise nature of $\mathrm{X}$ and $\mathrm{Y}$ however remains a blind spot, as does the operationalisation of trust.

Reference List

Algemene Rekenkamer (1997). Klantgerichtheid publieke dienstverlening. Den Haag: Algemene Rekenkamer.

Augoustinos, M. \& Walker, I. (1996). Social Cognition: an Integrated Introduction. London: Sage.

Bennett, Carolyn, Donald G. Lenihan, John Williams, and William Young. 2001. "Measuring Quality of Life: the Use of Societal Outcomes by Parliamentarians."

Bok, D. (2001). The Trouble With Government. Cambridge, MA: Harvard University Press.

Bouckaert, G. (1995). Remodeling Quality and Quantity in a Management Context. In: Public Productivity Through Quality and Strategic Management, eds. A. Halachmi and Geert Bouckaert. IOS Press

Bouckaert, G. (1998). Sustainable Development of Networks in a Governance Context. In: Spanning the Global Divide: Networking for Sustainable Delivery, eds; Francois Theron, Andries van Rooyen, and Frederik Uys. Stellenbosch: School of Public Management, University of 
Stellenbosch. pp. 40-56.

Bouckaert, G., Kampen, J. K., Maddens, B. \& Van de Walle, S. (2001). Klantentevredenheidsmetingen Bij De Overheid: Eerste Rapport Burgergericht Besturen: Kwaliteit En Vertrouwen in De Overheid. Leuven: Instituut voor de Overheid.

Conroy, D. K. 1. (1998). Client Satisfaction Measures: What Are Their Applications for Public Policy in Privatisation and Contracting Out ?, Paper Presented at the 1998 International Conference of the Australasian Evaluation Society, Proceedings Volume 2, Pp. 955-974. Melbourne, State of Victoria, Australia.

Das, H., Das, M. \& Mckenzie, F. (1995). Assessing the "will of the people": an investigation into town delivery satisfaction. Canadian Public Administration, 38, (1): 77-93.

Dinsdale, G. \& Marson, B. D. (1999). Citizen/client surveys: Dispelling myths and redrawing maps. Canadian Centre for Management Development.

Easton, D. (1965). A Systems Analyis of Political Life. New York.

Gamson, W. A. (1968). Power and Discontent. Homewood, Illinois: The Dorsey Press.

Goodsell, C. T. (1994). The Case for Bureaucracy: a Public Administration Polemic. 3rd ed. Chatham: Chatham House Publishers Inc.

Government of Western Australia (2000). 2000-01 Budget Statements Volume 1.

Hirschman, A. O. (1970). Exit, Voice, and Loyalty: Response to Decline in Firms, Organizations and States. Cambridge, MA: Harvard University Press.

Hofstede, G. H. (1980). Culture's Consequences: International Differences in Work-Related Values. Beverly Hills (Calif.): Sage.

Katz, D., Gutek, B. A., Kahn, R. L. \& Barton, E. (1977). Bureaucratic Encounters: a Pilot Study in the Evaluation of Government Services. Ann Arbor: Institute for social research.

Kofele-Kale, Ndiva. 1999 . "Good governance as political conditionality" [Web Page]. http://www.unesco.org/most/p95kale.htm.

Levi, M. (1996). A State of Trust. Florence: European University Institute/Robert Schumann Centre.

Light, Paul. C. and Judith M. Labiner. 2001. "A Vote of Renewed Confidence: How Americans View Presidential Appointees and Government in the Wake of the September 11 Terrorist Attacks." The Presidential Appointee Initiative. 12.

Mackie, J. L. (1965). Causes and conditions. American Philosophical Quarterly, 2, (4): 245-64. 
Miller, T. I. \& Miller, M. A. (1991). Standards of excellence: US residents' evaluations of local government services. Public Administration Review, 51, (6): 503-13.

Moore, N., Clarke, R., Johnson, S., Seargeant, J. \& Steele, J. (1998). People and Public Services: A Review of Research into People's Expectations and Experiences of Public Services. London: The Cabinet Office, The Office for Public Management \& Acumen.

Panel on civic trust and citizen responsibility. 1999. "A Government to Trust and Respect: Rebuilding Citizen-Government Relations for the 21st Century." .

Parry, G. (1976). Trust, distrust and consensus. British Journal of Political Science , 6, (2): 129-43.

Peckenpaugh, Jason. 2001. "Feds Top Private Firms in Customer Satisfaction." GovExec Daily Briefing 17 December 2001 .

Peters, B. G. (1995). Introducing the Topic. In: Governance in a Changing Environment, Guy B. Peters and Donald J. Savoie. Montreal \& Kingston: Canadian Centre for Management Development \& McGill-Queen's University Press. pp. 3-19.

Poister, T. H. \& Henry, G. T. (1994). Citizen Ratings of public and private service quality: a comparative perspective. Public Administration Review , 54, (2): 155-60.

Princeton Survey Research Associates \& Pew Charitable Trust (2000). Customers judge the performance of federal government agencies: report on the findings.

Programmabureau Overheidsloket (2000). Monitoren Van Geintegreerde Dienstverlening. Den Haag.

Roth, V. J., Bozinoff, L. \& MacIntosh, P. (1990). Public opinion and the measurement of consumer satisfaction with government services. Canadian Public Administration, 33, (4): 571-83.

Rouban, L. (1995). The Civil Service Culture and Administrative Reform. In: Governance in a Changing Environment, eds. B. G. Peters and D. Savoie. Montreal and Kingston: Canadian Centre for Management Development and McGill-Quen's University Press. pp. 23-54.

Schmidt, F. \& Strickland, T. (1998). Client satisfaction surveying: Common measurements tool. Canadian Centre for Management Development.

Servicebarometer AG. 2001. "Kundenmonitor Deutschland 2001 - Qualität und Kundenorientierung" [Web Page]. http://www.servicebarometer.de/kundenmonitor2001.

SIGMA (1998). Public opinion surveys as input to administrative reform. Paris: OECD.

Sims, H. (2001). Public confidence in government and government service delivery. Canadian Centre for Management Development. pp. 41. 
Stipak, B. (1979). Citizen satisfaction with urban services: potential misuse as a performance indicator. Public Administration Review , 39, (1): 46-52.

Tyler, T. R. (1990). Why People Obey the Law. New Haven (Conn.): Yale University Press.

Uslaner, E. M. (2002). The Moral Foundations of Trust. Cambridge: Cambridge University Press.

Van de Walle, S. (forthcoming). Context-specific images of the archetypical bureaucrat: persistence and diffusion of the bureaucracy stereotype. Public Voices.

Van de Walle, S. \& Bouckaert, G. (2003). Public service performance and trust in government: the problem of causality. International Journal of Public Administration , 26, (8-9).

van Kruchten, J. C. M. \& Peereboom, Sj. (1997). De Fiscale Monitor, Wat Vindt De Belastingplichtige Van De Belastingdienst. In: Evaluatieonderzoek in De Rijksdienst: Toepassingen En Ervaringen in De Praktijk, eds. A. J. M. Hendriks, H. C. Idema, T. J. Kliest, D. Meinders, and D. van der Vuurst.

World Bank (1992). Governance and Development. Washington DC.

Zeithaml, V. A., Parasuraman, A. \& Berry, L. L. (1990). Delivering Quality Service: Balancing Customer Perceptions and Expectations. London: The Free Press. 